Murni Kemala Dewi | Failure of Securitizing the Climate Change Issue at the United Nations Security Council (2007-2019)

Article

\title{
Failure of Securitizing the Climate Change Issue at the United Nations Security Council (2007-2019)
}

\author{
Murni Kemala Dewi ${ }^{1}$ \\ ${ }^{1}$ International Relations Department, Faculty of Social and Political Sciences, Universitas Indonesia, \\ West Java, Indonesia
}

\section{SUBMISSION TRACK}

$\begin{array}{ll}\text { Recieved } & : 09 \text { August } 2020 \\ \text { Final Revision } & : 06 \text { October } 2020 \\ \text { Available Online } & : 30 \text { November } 2020\end{array}$

\section{KEYWORD}

The Security Council, Climate Change, Securitization

\section{KATA KUNCI}

Dewan Keamanan, Perubahan Iklim,

Sekuritisasi

\section{CORRESSPONDENCE}

E-mail : murnikemaladewi99@gmail.com

\section{A B S T R A C T}

This paper describes the dynamics of debates on the securitization of climate change issue at the United Nations Security Council (UNSC), which took place from 2007 to 2019. Although there have been four open debates, the process of the securitization of climate change has failed. Prior studies discussing the same concern has only explained some of the reasons proposed in the debates, such as relating to the mandate of the UNSC, the division of work in the UN units, and whether the issue of climate change could be considered as a security issue. By applying the Externalist School of Securitization theory and using qualitative method which data comes from UNSC document and literature studies, this paper analyzes the relationship between sociolinguistics and socio-politics in the dynamics of the debates on the securitization of climate change at the UNSC and the roles of the UNSC permanent members. The main argument in this research is spotted on the existing rejection against the framing of climate change as a security issue by several permanent members, hence no mitigation policy can be mutually agreed upon. This has resulted in a failure in the process of securitizing the climate change issue at the UNSC (2007-2019).

\section{A B S T R A K}

Artikel ini memaparkan dinamika perdebatan mengenai sekuritisasi isu perubahan iklim di Dewan Keamanan Perserikatan BangsaBangsa (DK PBB) yang berlangsung dari tahun 2007 hingga 2019. Meskipun sudah ada empat debat terbuka mengenai isu ini di DK PBB, proses sekuritisasi isu perubahan iklim di DK PBB ternyata gagal. Kajian-kajian sebelumnya yang membahas isu yang sama hanya menjelaskan beberapa alasan yang dikemukakan dalam debat, seperti terkait mandat DK PBB, pembagian kerja di unit-unit PBB, dan apakah isu perubahan iklim bisa dianggap sebagai isu keamanan. Dengan menerapkan teori Externalist School of Securitization dan menggunakan metode kualitatif yang datanya berasal dari dokumen DK PBB serta studi literature, artikel ini menganalisis hubungan antara sosiolinguistik dan sosial politik dalam dinamika perdebatan tentang sekuritisasi isu perubahan iklim di DK PBB dan peran anggota tetap dalam perdebatan tersebut. Argumen utama dalam penelitian ini terletak pada adanya penolakan terhadap framing perubahan iklim sebagai isu keamanan oleh beberapa anggota tetap, sehingga tidak ada kebijakan mitigasi yang dapat disepakati bersama. Hal ini mengakibatkan gagalnya proses sekuritisasi isu perubahan iklim di DK PBB (2007-2019). 


\section{Introduction}

The definition of 'security' agenda has been a frequent topic of debates in International Relations (IR) studies. During the Cold War era, several different approaches to security issue developed in relation to conflict between the 'East and the 'West' ${ }^{1}$. However, the end of the Cold War came to shock policy makers and scholars. None of IR theories or security studies successfully predicted an end to the war ${ }^{2}$. Moreover, one of IR visions is to understand and mitigate (even to prevent if possible) the risks arising from war ${ }^{3}$. This has moved researchers and scholars to pay attention to another issue: globalization. The debate on globalization, among others, questions whether this arising phenomenon is a new case triggered by emerging communication and transportation, or actually an old phenomenon that has been long neglected ${ }^{4}$. However, the debate notices the emergence of non-governmental organizations (NGOs) and intergovernmental organizations*.

In addition to emerging new actors, globalization has also carried a new shape of 'war'. The new war has blurred the differences between the actual war and organized crimes and massive violations of human rights 5 . The arising war has different objectives, methods, and funding from the actual war and exists as a globalization product and a result of the emerging new technologies. Globalization has also raised issues threatening security, which are no longer only about military power, but have developed into non-traditional threats

\footnotetext{
${ }^{1}$ COT Institute for Safety, Security and Crisis Management (2007) "Notions of Security Shifting Concepts and Perspectives", (2007); p 3-61 accessed from www.transnationalterorism.eu on June 21st, 2020

2 ibid

${ }^{3}$ Lassa, Jonatan. "Global Governance of Disaster Risk Reduction : An Introduction to a New Analytical Framework", Jurnal Global, Vol.10 No.1,(2010); p. 17

${ }^{4}$ COT Institute for Safety, Security and Crisis Management (2007). "Notions of Security Shifting Concepts and Perspectives", (2007); p. 3-61 accessed from www.transnationalterorism.eu on June 21st, 2020

5 Kaldor, Mary (2012). "New and Old Wars 3rd Edition", Polity Press, (2012); p.2
}

including economic, social, environmental, health, and cultural threats. These new threats have special characteristics that distinguish them from traditional threats, such as that they do not centrally happen in a certain country, but can threaten multiple countries; they are not focused on geographic environments due to their nature of crossing national and regional borders; they are not focused on using military force, but the military becomes the last option if the threats turn into potential conflicts; and that they do not only attack states, but also individuals or humans themselves ${ }^{6}$. The new threats arise due to the existing human needs of feeling secure (human security), so that humans are put in the center of analysis ${ }^{7}$. The relationship between human security and the environmental, social, political and cultural issues will be the main attention. This becomes an important note as the social dimension of the issues has often been ignored. As in environmental problems, how the environmental degradation issues are associated with human survival and wellbeing would be assessed, then it would be linked to the arising social, economic, and political problems, which definitely can affect human security ${ }^{8}$.

A tie between environment and security has been the object of research published in recent decades. Since the early 1970 s, there has been a developing awareness that environmental problems are cross-border problems and need to be addressed at both national and international levels ${ }^{9}$. Environmentally destructive actions in a country affecting another country have made this issue an important concern among international policymakers. If the environmental degradation issues not

\footnotetext{
6 Tobing, Fredy Buhama Lumban. "Aktivitas Drug Trafficking sebagai Isu Keamanan yang Mengancam Stabilitas Negara”, Jurnal Global, Vol.5 No.1, (2002); p. 75-76

7 Little, Laura and Cocklin, Chris. "Environment and Human Security' in 'SAGE Handbooks of Environmental and Society",

SAGE Publishing, (2007), p.451

${ }^{8}$ ibid

9 Nirbito, Annisa. "Radikalisme dalam Aksi Pergerakan Lingkungan: Studi Kasus terhadap Earth Liberation Front (Periode
} 1996-2011)", Jurnal Global, Vol.15 No.2, (2013); p.164 


\section{Murni Kemala Dewi | Failure of Securitizing the Climate Change Issue at the United Nations Security Council (2007-2019)}

immediately resolved, it will cause changes in natural conditions and ultimately lead to scarcity of basic resources such as water which may lead to conflicts. Myers (1986) states that if the environmental foundations of a country run out, it will affect the economy, social and political order, and result in conflict ${ }^{10}$.

The happening climate change has caused environmental degradations, which leads to a security threat. Several regions, such as Africa, Oceania, and the Middle East, have experienced a climate change associated with the increasing number of conflicts in the region. In Oceania, the rising sea level means that people living around the coast have to move and enter other areas. This has led to conflicts, such as in the Solomon Islands and Bougainville ${ }^{11}$. Another international concern is a drought problem in Lake Chad, Africa. Lake Chad, one of Africa's largest sources of freshwater and livelihood source for the estimated 30 million people around, has rapidly disappeared due to an extreme drought brought by climate change ${ }^{12}$. This was then used by terrorist groups to recruit new members and resulted in rising cases of violence and conflict that jeopardized the estimated 10.7 million people living around the region ${ }^{13}$.

Security problems that occur across regions have resulted in efforts to raise the climate change issue as a security issue by using securitization measures to increasingly be carried out at the global level, including at the United Nations Security Council (UNSC) forum. This agenda was first initiated by the United Kingdom (UK) in 2007, serving as

\footnotetext{
10 Myers, N (1986). "The environmental dimension to security issues", The Environmentalist 6 (4),(1986); p. 251-257

11 Boege, Volker."Climate Change and Conflict in Oceania Challenges, Responses, and Suggestions for a Policy-Relevant Research Agenda', Toda Peace Institute, (2018) accessed from https://toda.org/assets/files/resources/policy-briefs/T-PB

17 Volker $\% 20$ Boege_Climate $\% 20$ Change $\% 20$ and $\% 20$ Conflict $\% 2$ 0in\%20Oceania.pdf, on March 26th, 2020.

${ }^{12}$ Usigbe, Leon. "Drying Lake Chad Basin Gives Rise to Crisis", Africa Renewal, (2019), accessed from https://www.un.org/africarenewal/magazine/december-2019-march2020/drying-lake-chad-basin-gives-rise-crisis, on March 26th, 2020
} 13 ibid the Presidency of 15-nation UNSC in April ${ }^{14}$. This initiation was well received, especially by those countries viewing that the climate change had affected their stability and security. However, since the initiation began, a targeted agreement have yet to be achieved. From a liberal point of view, regime ${ }^{15}$ and global governance ${ }^{16}$ play an important role in the debates on this issue. The ongoing debates on roles and functions of the UNSC, also the work division between related bodies at the UN, are major concerns that have not yet been concluded. Meanwhile, from a constructivist viewpoint, securitization ${ }^{17}$ and environmental security ${ }^{18}$ are contentious issues, especially if they relate to a motion whether climate change can be considered a security threat. Even if it is considered as a threat, then the question is about a necessary process to securitize the issue. The securitizing efforts by several regions ${ }^{19}$ for this issue are also raised to

\footnotetext{
${ }^{14}$ United Nations. "Security Council Holds First-Ever Debate on Impact of Climate Change on Peace, Security, Hearing Over 50 Speakers", (2007a), accessed from https://www.un.org/press/en/2007/sc9000.doc.htm on June 21st, 2020

${ }^{15}$ Cousins, Stephanie (2013. "UN Security Council: playing a role in the international climate change regime?", Global Change, Peace and Security, Vol. 25 (2), (2013); p. 191-210; Ng, Trina. "Safeguarding Peace and Security in our Warming World : A Role for the Security Council", Journal of Conflict \& Security Law, Vol. 15 (2), (2010); p. 275-300

16 Floyd, Rita. "Global climate security governance: a case of institutional and ideational fragmentation", Conflict, Security \& Development, Vol.15 (2), (2015); p. 119-146

17 Peters, Katie. "Disasters, climate change, and securitization: the United Nations Security Council and the United Kingdom's security policy”, Disaster, Vol.42(2), (2018); p. 196- 214; Corry, Olaf. "Securitization and 'Riskification': Second-order Security and the Politics of Climate Change", Millennium: Journal of International Studies, Vol. 40 (2), (2012); p. 235-258; Warner, Jeroen dan Boas, Ingrid. "Securitization of climate change: How invoking global dangers for instrumental ends can backfire", EPC: Politics and Space, Vol. 37(8), (2019); p. 1471-1488; Abrahams, Daniel. "From discourse to policy: US policy communities' perceptions of and approaches to climate change and security", Conflict, Security \& Development, Vol.19 No. 4,p. (2019): p.323345

18 Floyd, Rita.'The Environmental Security Debate and its Significance for Climate Change", The International Spectator, Vol. 43 (3),(2008); p. 51-65

19 Brown, Oli et al."Climate Change as the 'New' Security Threat: Implications for Africa", International Affairs (Royal Institute of International Affairs 1944), Vol. 83 (6,) (2007); p. 1141-1154; Dupont, Claire. "The EU's collective securitisation of climate change", West European Politics,Vol. 42 (2), (2019); p. 369-390; Lucke, Franziskus von, et al. "What's at Stake in Securitising Climate Change? Towards a Differentiated Approach", Geopolitics, Vol. 19,(2014); p. 857-884; Seiyefa, Ebimboere. "How climate change impacts on regional security in West Africa: Exploring the link to organised crime", African Security Review, (2019); p. 2-13;
} 
become considerations on the debates at the UNSC.

Findings of previous research concluded that several issues debated at the UNSC regarding the climate changesecuritizing efforts are (1) related to the mandate / main function of the UNSC itself; (2) the work division at the UN between the UNSC and other climate change-related bodies; and (3) related to whether climate change can be categorized as a security threat. From the literature review, there was no discussion on ties between sociolinguistics and socio-politics in the dynamics of the debate on the climate change issue at the world's largest multilateral institution and on the UNSC permanent members' role in determining whether the climate change issue can be identified as a security threat through the institution's mechanism. Therefore, the research question is "Why has the UNSC failed to agree on climate change as a global threat since the securitization process began in 2007?". The Externalist School of Securitization (ESS) framework was applied for analyzing four debates related to the securitization of climate change issue at the UNSC since the UK raised the motion in 2007 until the recent debate in 2019.

\section{Research Method}

To answer the research question, this study used a qualitative method. The main data was from the UNSC resolutions and minutes of documents related to the climate change securitization issue at the UNSC (20072019). Meanwhile, secondary data was obtained from books, journals, and articles from various online and print media. The data method was archival research and media (especially online media). After all the data was collected, a triangulation of findings was conducted to examine the validity and reliability of the collected data. The triangulation was carried out by comparing

Hartmann, Betsy. "Rethinking Climate Refugees and Climate Conflict : Rhetoric, Reality and the Politics of Policy Discourse", Journal of International Development, Dev. 22, (2010); p.233-246 the data obtained for the study with the findings in accordance with the observation. This research paper consists of introduction, analytical framework, research method, discussion, and conclusion.

\section{Analytical Framework}

Over the last decade, securitization theories have opened new pathways to study security in the IR. In the security studies, securitization theories refer to diverse and comprehensive issues. Huymans (1998) states that securitization is the most comprehensive and continuous exploration which is the implication of expanding the security agenda in security studies ${ }^{20}$. According to Buzan, Waever, and Wilde (1998), securitization is a political step taken outside the existing rules of the game ${ }^{21}$. This step will then frame an issue in a political policy or on top of a political policy. Securitization can be seen as an extreme way of political endeavor. The distinguishing feature of securitization is its specific rhetorical structure, especially regarding the issue of survival and the priority of action. The issue should be immediately addressed before it is too late. Kurniawan (2018) indicates four important subjects to understand a security situation which require securitization, namely threats, threatened objects, emergencies, and the existence of prevention policy making that is out of the ordinary 22 .

The Copenhagen School (CS) frames the concept of securitization as a 'speech act' that could move certain social issues from democratic institutions under political control to emergencies with limited

\footnotetext{
${ }^{20}$ Huysmans, Jef. "Revisiting Copenhagen: Or About the Creative Development of a Security Studies Agenda in Europe", In LuizaMaria Filimon, "An Overview of the Copenhagen School's Approach to Security Studies : Constructing (In) Security Through Performative Power", Asociatia Romana pentru Studii Baltice si Nordice, (2016); p. 53

${ }^{21}$ Buzan, Barry, Waever, Ole and Wilde, Jaap de. "Security: A New Framework of Analysis", London :Lynne Riener Publisher, (1998); p. 23

${ }^{22}$ Kurniawan, Yandri."The Politics of Securitization in Democratic Indonesia", Palgrave Macmillan, (2018); p.19
} 


\section{Murni Kemala Dewi | Failure of Securitizing the Climate Change Issue at the United Nations Security Council (2007-2019)}

democratic control ${ }^{23}$. The success of the securitization steps depends on the 'actors' involved. These actors will later connect the existing 'threat' to certain objects, then their steps could be accepted by the audience (public) ${ }^{24}$. Therefore, when an elite uses the word 'securitization', he/she has moved an issue to a particular field, and thus claimed the privilege of using any means necessary to block the issue. However, the CS securitization concept, according to the author, does not precisely describe the securitization process in international institutions.

Many international actors are involved at the international institutions' decision making. It can be difficult to differentiate between the actor and the audience ${ }^{25}$. Therefore, Beugers (2010) emphasizes that securitization is not only seen from individual speech act, but also must be understood by the overall process (both rhetorically and linguistically) carried out by many actors in international institutions ${ }^{26}$. Meanwhile, Jackson (2006) states that to understand the securitization process in international institutions, one should also understand the attitudes of various countries' representatives who act as audiences in the institutions ${ }^{27}$. The countries that become the audiences may have different perspectives on the issue that they want to securitize and take a stand / release a speech act that can preclude the securitization process. The ESS agree that in securitization efforts, there is a relationship between socio-political context (the relationship between actor and audience) and

\footnotetext{
23 Waever, O."Securitization and Desecuritization". In: R.D. Lipschutz (ed.). "On Security”, New York: Columbia University Press, (1995); p. 46-87.

${ }^{24}$ Buzan, Barry, Waever, Ole and Wilde, Jaap de. "Security: A New Framework of Analysis", London :Lynne Riener Publisher, (1998); p. 23

25 Bueger, Christian. "Security as Performation: Securitization, Piracy and the United Nations Security Council" In Zakopalova, Dagmar (2012), "Contextualizing the Process of Securitization: Construction of Security in the United Nations",MA Thesis Swiss Federal Institute of Technology Zurich, (2012); p. 12-14

26 ibid

27 Jackson, Nicole J. "International Organizations, Security Dichotomies and the Trafficking of Persons and Narcotics in PostSoviet Central Asia: A Critique of the Securitization Framework", Security Dialogue, 37 (3),(2006); p.299-317
}

socio-linguistic context which is applied to understand and construct the rhetorical / linguistic meaning delivered ${ }^{28}$. The ESS also provides three perspectives on the placement of international institutions in the securitization process. The first placement is to be a functional actor who is capable of influencing the dynamics of the securitization process. The second is to be a securitizing actor** who can carry out securitization. The third is to be a platform where the securitization process is carried out $^{29}$.

The securitization process in international institutions, according to the EES, is triggered by an attempt to frame an issue into the concept of security. This initial process is also known as the securitization move $^{30}$. This effort is usually initiated by a window of opportunity, which arises due to either public upheaval or the emerging issues $^{31}$. Furthermore, arguments that can support this issue to become a security issue will be elaborated and presented by the securitizing actor to the audience. These intermediate steps to describe the ongoing debates among the actor and the audience are referred to as diagnostic success, prognostic success, and motivational success variables. These three variables represent the way the audience accepts or rejects the arguments proposed by the actor. By looking at the level of success in each intermediate step, it is expected to possibly predict the success of securitization (the level of success of the issue which is raised to a security issue) based on the resulting discursive and material effects ${ }^{32}$.

\footnotetext{
28 Zakopalova, Dagmar. "Contextualizing the Process of Securitization: Construction of Security in the United Nations",MA Thesis, Swiss Federal Institute of Technology Zurich, (2012)

${ }^{29} \mathrm{ibid}$

${ }^{30}$ ibid

31 Kingdon, John W. "Agendas, alternatives and public policy", Boston: Little Brown In Zakopalova, Dagmar. "Contextualizing the Process of Securitization: Construction of Security in the United Nations", MA Thesis Swiss Federal Institute of Technology Zurich, (2012)

32 Zakopalova, Dagmar. "Contextualizing the Process of Securitization: Construction of Security in the United Nations",MA Thesis, Swiss Federal Institute of Technology Zurich, (2012)
} 
Murni Kemala Dewi | Failure of Securitizing the Climate Change Issue at the United Nations Security Council (2007-2019)

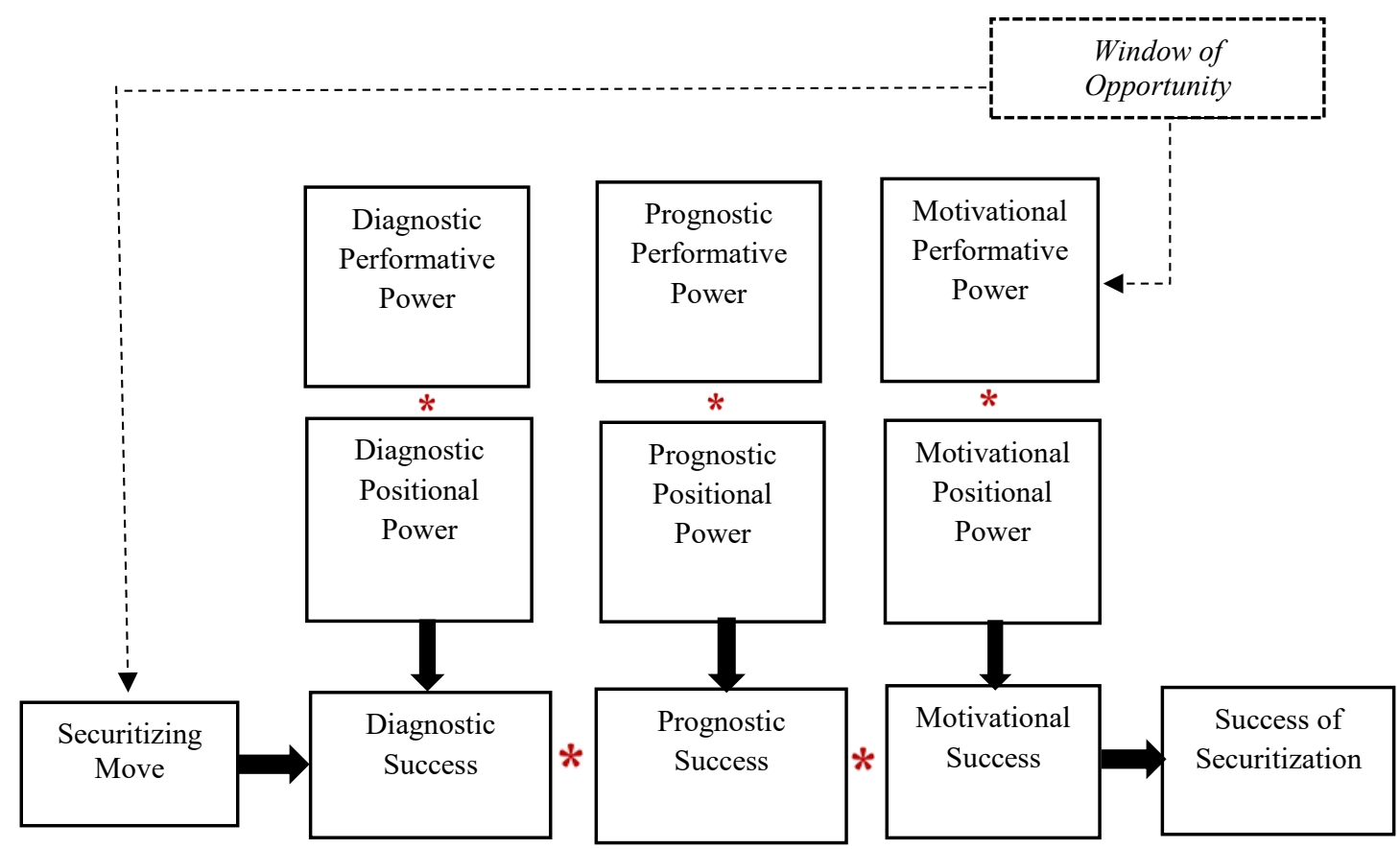

Figure 1: Model of the Securitization Process in International Institutions (Zakopalova, 2012)

According to Zakopalova (2012), in the securitization process in international institutions, referring to the above figure, there are several variables as follows ${ }^{33}$ :

1. Securitizing move (how the issue is first raised): The proposal to undertake securitization is the beginning of the securitization process. Securitizing move can also be understood as an attempt to frame a certain problem into a security issue (Zakopalova, 2012). This step can be carried out by any actor who has access to the institution. The actor will then elaborate and present the security issue to the audience.

2. Diagnostic success: In this variable, the actor's ability to persuade the audience will be observed. This variable is influenced by two elements, namely diagnostic positional power \& diagnostic performance power of the actor. Diagnostic positional power is the ability of securitizing actors to influence the collective identification of security problems in their sociopolitical community. This ability comes from the distribution of power contained in the socio-political community; for example the actor is a permanent member with privilege in that international institution. Meanwhile, the diagnostic performative power is to see the actor's ability to make a framing / persuade the audience to agree upon the issue.

3. Prognostic success: This variable determines the extent to which the suggested preventive policies can be accepted by the audience. This variable is also influenced by two elements, namely Prognostic positional power \& Prognostic performative power. Prognostic positional power is the actor's ability to influence the audience in making policies to address the issues raised. Here it will be seen whether the actors raising the issue have reliable 
experience in making policies related to similar issues. Meanwhile, the prognostic performative power looks at the compatibility of texts in conceptualizing the policies to be taken. To understand whether the recommended preventive policies are an appropriate response to addressing the issue in question.

4. Motivational success: This variable shows the extent to which the issue presented is understood by the audience as a security problem, whether the issue is considered irrelevant, relevant, serious, or urgent. This variable shows a type of 'safety quality' the audience agree upon the issue raised by the actor. This variable is influenced by motivational positional power \& motivational performative power. Motivational positional power which looks at the ability / appropriateness of the actor to motivate the action to be taken on the issue being intended. For example, looking at the personality (character) of the securitization actor, whether the actor has the right resources to motivate the audience to agree on the issue to be raised or the actor can use "coercion" or incentives to persuade the audience. Motivational performative power is the language ability used to motivate action. It can be seen to what extent the conveyed language reflects the motivation and mobilization of the audience and how it explains why the issue needs to be considered a serious security problem and requires the action proposed. It revolves around whether the delivery show the arising problems resulted by the addressed issue and the extent to which these problems threaten security if securitization is not carried out, or whether the security language used is contextually appropriate in describing the issues raised.

5. Success of Securitization (How does the position of the issue have a discursive \& material effect): This variable aims to determine the securitization level of the issued policy and how the issue is handled. This is to answer the question of either the issue can be accepted or rejected as a security threat. If it is accepted, then the question is about the extent of the threat level from the issue and how to overcome it. The success of securitization of an issue, whether or not it is accepted as a security threat, is caused by an internal factor which is how the audience's attitude in accepting the issue presented (discursive effect) and an external factor which is a kind of action the audience agrees to deal with the issue (material effects) ${ }^{34}$.

\begin{tabular}{|c|c|c|}
\hline $\begin{array}{c}\text { Value of the } \\
\text { variable }\end{array}$ & $\begin{array}{l}\text { Discursive } \\
\text { effects }\end{array}$ & Material effect \\
\hline $\begin{array}{c}\text { Failed } \\
\text { securitization }\end{array}$ & Non-issue & $\begin{array}{c}\text { No } \\
\text { countermeasures }\end{array}$ \\
\hline Politicization & Political concern & $\begin{array}{c}\text { No } \\
\text { countermeasures } \\
\text { Standard } \\
\text { countermeasures }\end{array}$ \\
\hline $\begin{array}{c}\text { Latent } \\
\text { securitization }\end{array}$ & $\begin{array}{l}\text { Security concern } \\
\text { Existential threat }\end{array}$ & $\begin{array}{c}\text { No } \\
\text { countermeasures }\end{array}$ \\
\hline $\begin{array}{l}\text { Low success of } \\
\text { securitization }\end{array}$ & Security concern & $\begin{array}{c}\text { Standard } \\
\text { countermeasures }\end{array}$ \\
\hline \multirow[t]{2}{*}{$\begin{array}{l}\text { Medium success } \\
\text { of securitization }\end{array}$} & Existential threat & $\begin{array}{c}\text { Standard } \\
\text { countermeasures }\end{array}$ \\
\hline & Security concern & $\begin{array}{c}\text { Exceptional } \\
\text { countermeasures }\end{array}$ \\
\hline $\begin{array}{l}\text { High success of } \\
\text { securitization }\end{array}$ & Existential threat & $\begin{array}{c}\text { Exceptional } \\
\text { countermeasures }\end{array}$ \\
\hline
\end{tabular}

Table 1: Levels of Discursive and Material Effects in the Securitization Process in International Institutions (Zakopalova, 2012)

${ }^{34}$ Salter, Mark B. "When Securitization Fails: The Hard Case of Counter-Terrorism Programs' p.116-131 In Zakopalova, Dagmar. "Contextualizing the Process of Securitization: Construction of Security in the United Nations", MA Thesis Swiss Federal Institute of Technology Zurich, (2012) 
Murni Kemala Dewi | Failure of Securitizing the Climate Change Issue at the United Nations Security Council (2007-2019)

\section{Discussion}

\section{The Climate Change Securitization Move at the United Nations Security Council}

The climate change securitization at the UNSC was first initiated by the UK, while the country was serving as the Presidency of the 15-nation UNSC for the month of April, through an official letter to the UN dated on April 5, 2007 No. SC/2007/186 addressed to the President of the $\mathrm{UNSC}^{35}$. This letter expressed the approval of the UNSC members for a proposal submitted by the UK for an open debate on a theme of Energy, Security and Climate on April 17 to explore the relationship between energy, security, and climate $^{36}$. The objective of this debate is to raise an awareness of the risks of future security issues that are significant to the international community, to promote a shared understanding of the risks of these issues, and to explore ways of dealing with them $^{37}$ with a major focus on the security implications of climate change. This step was supported by Ban Ki Moon at his term of serving as the UN Secretary General by issuing an official statement during an open debate on April $17^{38}$. However, in this initial debate, the UK's proposal to securitize the climate change was rejected by Russia and China, another two permanent members of the UNSC.

Although the initial debate had not reached a consensus, the UK's effort attracted the attention of other UN member states, including the UNSC permanent members which are the United States, China, France, and Russia. After the issue was in

\footnotetext{
35 United Nations. "Security Council Holds First-Ever Debate on Impact of Climate Change on Peace, Security, Hearing Over 50 Speakers", (2007a), accessed from https://www.un.org/press/en/2007/sc9000.doc.htm on June 21st, 2020

36 United Nations. "S/2007/186", (2007b) accessed from https://www.securitycouncilreport.org/atf/cf/\%7B65BFCF9B6D27-4E9C-8CD3-

CF6E4FF96FF9\%7D/CC\%20S2007\%20186.pdf on June 21st, 2020 37 ibid

38 United Nations. "Statement at the Security Council debate on energy, security and climate", (2007c), accessed from https://www.un.org/sg/en/content/sg/speeches/2007-04-

$17 /$ statement-security-council-debate-energy-security-and-climate, on June 25th, 2020
}

motion in the early open debate in 2007 , the UN member countries from the Least Developed Countries and Small Island Developing States adopted three resolutions. The three resolutions were the Resolution 62/86 dated on 10 December 2007 concerning Protection of Global Climate for Present and Future Generations of Mankind, the Resolution 63/32 dated on 26 November 2008 regarding Protection of Global Climate for Present and Future Generations, and the Resolution 63/281 dated on 11 June 2009 concerning Climate Change and Its Possible Security Implications. These resolutions gave pressure to the UN General Assembly (UNGA) to pay more attention to the climate change issue and its implications for security. This urge was then responded to by the UNGA through a report issued by the UN Secretary General No. A/64/350 dated on 11 September 2009 with the theme "Climate Change and Its Possible Security Implications". In the Secretary General's report, the climate change issue was deemed a threat which was also seen as 'threat multiplier' ${ }^{39}$.

\footnotetext{
"Climate change is often viewed as a "threat multiplier"***, exacerbating threats caused by persistent poverty, weak institutions for resource management and conflict resolution, fault lines and a history of mistrust between communities and nations, and inadequate access to information or resources..." 40
}

The report also identifies a range of threats related to climate change that deserve attention and increases the preparedness of the international community for loss of territory, loss of citizenship, increasing number of refugees, insufficiency of water resources, melting of glaciers, and disputes about the opening of the Arctic for resource exploitation and trade. With this report from the UNGA, the UNSC is expected to take some appropriate preventive actions.

However, in the second open debate initiated by Germany while serving as President of the UNSC, different opinions

\footnotetext{
39 United Nations. "A/64/350: Climate change and its possible security implications", Report of the Secretary-General, (2009) 40 ibid
} 
surfaced among the five permanent members of the UNSC. The UK, France, and the United States agreed with this agenda, but China and Russia again took a stand against it. The debate was taking place on July 20 , 2011 with the theme "Maintenance of International Peace and Security: Impact of Climate Change"41. The following debate was then happening on July 11, 2018, initiated by Sweden while serving as the UNSC President. This debate with the theme "Maintenance of International Peace and Security: Understanding and Addressing Climate-related Security Risks" remained uncertain on the UNSC's attitude to the securitization of climate change issue. However, interestingly, there were some change in the attitude composition of the UNSC permanent members. China, who previously did not agree with the issue, then accepted it. While on the other hand, the United States, which previously accepted the issue, then showed a disagreement ${ }^{42}$. The last debate took place on January 25, 2019, which began with a letter No. S/ 2011/408 from the representative of the Dominican Republic, who at that time served as President of the UNSC, to the Secretary General on January 2, 2019 ${ }^{43}$. At this fourth open debate, the permanent members still showed the same attitude as before. Three members agreed (the UK, France, and China) and two members disagreed (Russia and the United States). The four debates which took place at the UNSC would be analyzed to identify what kind of response and debates among actors and the audience (especially the UNSC permanent members) on measures for the securitization of climate change issue.

\section{Variable of Diagnostic Success for Securitization of Climate Change at the UNSC}

${ }^{41}$ United Nations. "S/PV.6587: Maintenance of international peace and security: Impact of climate change", (2011)

42 United Nations. "S/PV.8307: Maintenance of international peace and security: Understanding and addressing climate-related security risks, (2018)

${ }^{43}$ United Nations. "S/PV.8451: Maintenance of international peace and security: Addressing the impacts of climate-related disasters on international peace and security", (2019)
Given that the supporters of this securitization issue are diverse, the diagnostic framework for this issue differs among the securitizing actors. The UK, as the first initiator, mentioned the UNSC's role "... to maintain international peace and security, including the prevention of conflict 44". The UK's attitude indicates the state's framing to the climate change issue in the security concept as 'the root causes of conflict'. In the UK's perspective, climate change '... will exacerbate some of the core drivers of conflict ${ }^{35}$. The British statement was reaffirmed by Ban Ki Moon who also framed the issue as the root causes of conflicts.

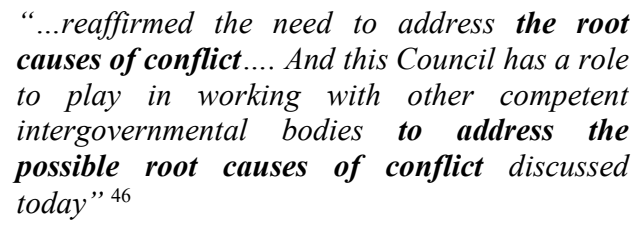

The framing by the UK in the first debate stimulated some responses from the audience, especially from the fellow permanent members. France approved the framing and firmed that climate change was '... among the main threats to the future of humankind' with possible impact on peace and security ${ }^{47}$. Meanwhile, the United States admitted that climate change and security '...were fundamentally linked'48. However, Russia and China had different perspectives of the framing. China considered climate change was properly assumed as '.... threat to the sustainable development'49, while Russia requested the UNSC '...to avoid panicking and overdramatizing the situation' and stated that the UNSC '...should only

\footnotetext{
44 United Nations."S/PV.5663: Energy, Security and Climate", (2007d)

45 ibid

46 United Nations. "Statement at the Security Council debate on energy, security and climate", (2007c), accessed from https://www.un.org/sg/en/content/sg/speeches/2007-04-

17/statement-security-council-debate-energy-security-and-climate, on June 25th, 2020

47 United Nations."S/PV.5663: Energy, Security and Climate", (2007d)

48 ibid

49 ibid
} 
deal with the consideration of questions that directly relate to its mandate, 50 .

On the second open debate, Germany was the actor that framed the climate change issue as '...a driver of conflict' ${ }^{\prime 51}$. Besides, Ban Ki Moon as the UN Secretary General had firmly stated that the issue was a threat for the world peace and security ${ }^{52}$. There again were some diverse opinions from the permanent members on this issue. The United States said that 'climate change has very real implications for peace and security' ${ }^{53}$. The UK expected the UNSC to consider the climate change as 'emerging threat' for security. France also released a statement on behalf of the European Union confirming that '...climate change has an immense destabilizing potential and could multiply the threats to peace and security in the most fragile regions and States' ${ }^{54}$. However, Russia firmly stated '...skeptical...' on endeavors of the actors to make the climate change issue as the security agenda $^{55}$. Meanwhile, China said that 'climate change may affect security, but it is fundamentally a sustainable development issue' though, and for them, the UNSC 'lacks expertise in climate change and the necessary means and resources' in handling the climate change issue ${ }^{56}$.

Then, on the third debate, Sweden as the actor tried again to raise the climate change issue and frame the issue as 'security risk' which affected the stability of security in several the world's regions ${ }^{57}$. The Swedish statement was then agreed by the UN Deputy Secretary General of 2018, Amina Mohammed, who said "...climate change is a real threat and is proceeding at a relentless pace' and it had created a security instability in several countries, especially countries

\footnotetext{
50 ibid

${ }^{51}$ United Nations. "S/PV.6587: Maintenance of international peace and security: Impact of climate change", (2011)

52 ibid

53 ibid

54 ibid

55 ibid

${ }^{56}$ ibid

${ }^{57}$ United Nations. "S/PV.8307: Maintenance of international peace and security: Understanding and addressing climate-related security risks, (2018)
}

vulnerable to climate change risks ${ }^{58}$. The UNSC permanent members, as the audience on the ongoing debate, again gave different responses. Interestingly, on the third debate, two permanent members, the United States and China, showed changes in their attitude. The United States, who previously stated that climate change gave a real implication on security, then on the ongoing debate stated that the climate change issue was a 'sustainable development' issue. While, China who previously showed no interest to discuss this issue, then on the running debate said that international community should prepare a shared new security concept to 'properly tackle climate-related security risks 59 .

On the fourth debate in 2019, the Dominican Republic highlighted an urgent relationship between environmental and security issues. The state said that climate change is an 'unconventional threat' for security ${ }^{60}$. The UK argued '...no doubt that climate-related security challenges are

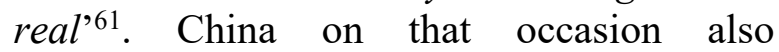
confirmed that the climate change issue was already 'undermining peace and stability' ${ }^{62}$. France said that 'the consequences of climate change on security is considerable' and it affected social, economy, health, and other factors, which would contribute to domestic and international crises ${ }^{63}$. On the other hand, Russia remained upholding their position as the party disapproving climate change issue as security issue. For Russia, '...climate change is not a universal challenge in the context of international security' ${ }^{64}$. The United States only made a statement that climate change was a 'disaster' that needed an international cooperation to carry out 'post-disaster recovery' 65 .

\footnotetext{
${ }^{58}$ Ibid

59 ibid

${ }^{60}$ United Nations. "S/PV.8451: Maintenance of international peace and security: Addressing the impacts of climate-related disasters on international peace and security", (2019)

${ }^{61}$ ibid

62 ibid

63 ibid

64 ibid

${ }^{65} \mathrm{ibid}$
} 
From these four debates, the efforts made by the actors to frame the climate change issue as a security issue gained some quite strong contradictive opinions from several permanent members who became the audience. Russia had been one audience that firmly refused the issue to be framed as the security threat. The Russia's refusal was probably because global warming causes the Arctic region easier to navigate than ever as the ice around the region is melting ${ }^{66}$ and most of Arctic region belong to the Russian region, so that the existing vast resources in the Arctic will greatly benefit Russia. Meanwhile, China and the United States showed uncertain attitudes to the framing of the issue, which was influenced by their own domestic conditions. The different attitude of the United States to the issue happened under the President Trump's administration, while China was first showing disapproval of the issue because they did not want the issue to restrict their energy consumption for their needs of industrialization and economic development ${ }^{67}$. However, after China developed renewable energy, it has evolved to be a country that is responsible for efforts to reduce global carbon emissions ${ }^{68}$.

\section{Variable of Prognostic Success for the Securitization of Climate Change at the United Nations Security Council}

Regarding the prognostic success variable, the existing opinions and debates were not much different like in the diagnostic phase. In the process of the debate on climate change issue, the actors offered a vague prognostic frame if compared to the diagnostic frame. They emphasized the importance of climate change policy which is 'better, stronger and more effective' than the policy made through another UN forum such

\footnotetext{
${ }^{66}$ Blank, Stephen. "Russia exploits climate change in the Arctic, ignoring threat to infrastructure", The Hill, (May 13. 2019) accessed from https://thehill.com/opinion/international/443402russia-exploits-climate-change-in-the-arctic-ignoring-threat-to on June 28th, 2020

${ }^{67}$ Chotimah, Hidayat Chusnul.“ Analisis Strategi Keamanan Energi Cina dalam Upaya Penurunan Emisi Karbon melalui Pendekatan Konstruktivisme”, Jurnal Global, Vol. 19 No. 1 (2017) ; p. 29-43 68 ibid
}

as $\mathrm{UNFCCC}^{69}$. They also expected the UNSC to be able to issue a consensus which approved that climate change issue was a security threat ${ }^{70}$. The supporters of the climate change securitization issue also delivered some proposals that expected the UNSC to issue policy that can overcome climate change issue through the increases in funding, defense, sustainable development, and international cooperation.

The refusing audience such as Russia responded this concern by emphasizing all the UNSC members that climate change issue is outside the UNSC's responsibilities. For Russia, there remains other bodies than the UNSC that can issue more proper policies, such as the UNFCCC or World Meteorological Organization (WMO). The audience who disapproved the securitization issue also confirmed that the long existing policies, such as Kyoto Protocol, Paris Agreement or Mauritius Strategy are policies which have already shown international endeavors in overcoming the climate change issue $^{71}$. Even Russia also released a speech act that requested all the UNSC members to give chances to all the UN bodies to be responsible for handling the climate change issue and let those bodies 'do their work in peace 72 .

\section{Variable of Motivational Success for the Securitization of Climate Change at the United Nations Security Council}

As shown by the diagnostic and prognostic variables, the audience are not sure about the 'security quality' related to the climate change issue, especially Russia.

\footnotetext{
69 United Nations."S/PV.5663: Energy, Security and Climate", (2007d)

${ }^{70}$ United Nations. "S/PV.8451: Maintenance of international peace and security: Addressing the impacts of climate-related disasters on international peace and security", (2019)

71 United Nations."S/PV.5663: Energy, Security and Climate", (2007d); United Nations. "S/PV.6587: Maintenance of international peace and security: Impact of climate change", (2011); United Nations. "S/PV.8307: Maintenance of international peace and security: Understanding and addressing climate-related security risks, (2018); United Nations. "S/PV.8451: Maintenance of international peace and security: Addressing the impacts of climaterelated disasters on international peace and security", (2019)

${ }^{72}$ United Nations. "S/PV.8307: Maintenance of international peace and security: Understanding and addressing climate-related security risks, (2018)
} 
Although not all of the audience have the same point of view, the permanent members have veto rights which can deter any decision or policy further issued by the UNSC. This is in accordance with Article 27 (3) in which all the UNSC's decisions must be made with 'the concurring votes of the permanent members" ${ }^{13}$. Therefore, the approval from all the permanent members is needed to make the climate change issue as a security issue. However, an endeavor of another permanent member who approved and acted as the actor, starting from the first to the last debate, had failed to convince Russia to securitize the climate change issue. The use of military language such as 'security challenge', 'security risk' nor threats against 'peace and security'74 still could not motivate Russia until the last debate round. Even the United States, who previously took a stand against the issue on the last two debates, did not use a military language such as 'security' in their speech act on the last debate ${ }^{75}$. Even though the securitization-opposing audience admitted that conditions such as loss of the region due to rising sea levels, the increasing number of refugees who lost their homes, an increase in disaster, health threat risks, emerging economic disruption, political instability, up to conflicts over resources and foods linked with climate change issue are cause for concerns, they also reaffirmed that the UNSC ' has neither the specialized expertise nor the tools to put together viable solutions for effectively combating climate change. ${ }^{, 76}$.

\footnotetext{
73 United Nations. "UN Security Council Working Methods: The Veto", (2020), accessed from https://www.securitycouncilreport.org/un-security-councilworking-methods/the-veto.php, on June 28th, 2020

74 United Nations."S/PV.5663: Energy, Security and Climate", (2007d); United Nations. "S/PV.6587: Maintenance of international peace and security: Impact of climate change", (2011); United Nations. "S/PV.8307: Maintenance of international peace and security: Understanding and addressing climate-related security risks, (2018); United Nations. "S/PV.8451: Maintenance of international peace and security: Addressing the impacts of climaterelated disasters on international peace and security", (2019)

${ }^{75}$ United Nations. "S/PV.8451: Maintenance of international peace and security: Addressing the impacts of climate-related disasters on international peace and security", (2019)

${ }^{76}$ United Nations. "S/PV.8307: Maintenance of international peace and security: Understanding and addressing climate-related security risks, (2018)
}

\section{Success of Securitization of Climate Change Issue at the United Nations Security Council}

Of all the process, it can be seen that the actors' effort to securitize climate change at the UNSC had failed because not all the audience (specifically the UNSC permanent members) shared the same concern on the urgency and relevance of climate change threat to security, as concerned by the securitizing actor (motivational success). In addition, there were different perspectives of the identification of the issue (diagnostic success), in which the audience performed a skeptical attitude to framing of the climate change issue in security context. This uncertainty is also reflected in countermeasures policy (prognostic success) made. Both the actor and the audience had not yet agreed upon what the countermeasures policy that should be made by the UNSC in overcoming the climate change issue. As an agreement between actors and audience related to framing of the securitization issue had not yet been achieved, the discursive effect was into "nonissue' category (considered not as a security issue). Meanwhile, from the first debate in 2007 to the last debate in 2019, the UNSC has yet to issue any policy related to the countermeasures of climate change issue, so that the material effect was categorized 'no countermeasure' (no policy agreed). Thus, the success of securitization for the climate change issue at the UNSC, as observed from the early to the last debate (2007-2019), has failed.

\section{Conclusion and Recommendation}

The UNSC has been facing new challenges due to the emerging globalization, yet mechanism at the UN is considered not adaptable to the current condition of the international environment, especially in overcoming non-traditional issues which include climate change. The veto rights privilege of the UNSC permanent members has made the process of securitizing an issue at the institution really depend on the 
permanent members' approval. The four open debates at the UNSC showed dynamics that not all the permanent members shared the same perspective in facing the climate change issue. This paper aimed to describe the dynamic process of securitizing the climate change issue at the UNSC and the role of context in the analysis on the issue. The contextual analysis of a securitization process adapted the ESS theoretical framework, which produces a model of the process, to the decision-making levels at the UN. This contextual feature will help trace the relationship between text and actors (the relationship between sociolinguistics and socio-politics) which in turn will provide a better understanding of the securitization process at the UNSC and why this process was successful or not. The failure of actors to frame this issue in the security context has resulted in no agreement in making countermeasures policy. This failure was mainly triggered by the attitude of the audience (especially permanent members) such as Russia, who rejected framing the issue into a security context and considered policies issued by other UN bodies, outside the UNSC, to be sufficient to solve the problem of climate change. This refusal from the UNSC permanent members has resulted in the failure of securitizing the climate change issue, even though the process had occurred from 2007 to 2019.

Notes:

* Keck \& Sikkink (1998) called the new actor by the term transnational advocacy networks.

** These functional actor and securitizing actor are actually discussed in the CS (Buzan.1998. p.36), but more in units contained within a country.

*** Threat multiplier itself is a term popularized in 2007 by a report from the Center for Naval Analysis, a think tank that focuses on security, entitled "National Security and the Threat of Climate Change" (Daniels, 2019). The use of a 'threat multiplier' framework shows that the impacts of climate change will not cause conflict, but can accelerate, exacerbate, or trigger conflict. Meanwhile, Sherri Goodman, a senior strategist at the Center for Climate and Security and the Secretary General of the International Military Council on Climate and Security (IMCCS) explained that the threat multiplier is when extreme weather and lack of water resources creates a risk of instability in the political field and increases the potential for terrorism or other security threats (Werrell \& Femia, 2019). According to her, climate change is a "stressor" that can threaten national security. This has generated pressure from various parties, that the state must immediately take action to ensure public safety by securitizing the climate change issue, not only at the state level, but also at the regional and world levels. 
Murni Kemala Dewi | Failure of Securitizing the Climate Change Issue at the United Nations Security Council (2007-2019)

\section{REFERENCES}

Abrahams, Daniel. "From discourse to policy: US policy communities' perceptions of and approaches to climate change and security", Conflict, Security \& Development, Vol.19 No. 4,p. (2019): p.323-345

Balzacq, T. "The Three Faces of Securitization: Political Agency, Audience and Context'; Stritzel, Holger. "Towards a Theory of Securitization: Copenhagen and Beyond"; McDonald, M. "Securitization and the Construction of Security" In Does, Antonio, "The Construction of The Maras: Between Politicization and Securitization", Graduate Institute Publications, Geneva, (2013) accessed from https://books.openedition.org/iheid/719?lang=en on June $21^{\text {st }}, 2020$

Blank, Stephen. "Russia exploits climate change in the Arctic, ignoring threat to infrastructure", The Hill, (May 13. 2019) accessed from https://thehill.com/opinion/international/443402-russia-exploits-climate-change-inthe-arctic-ignoring-threat-to on June $28^{\text {th }}, 2020$

Boege, Volker. "Climate Change and Conflict in Oceania Challenges, Responses, and Suggestions for a Policy-Relevant Research Agenda', Toda Peace Institute, (2018) accessed from https://toda.org/assets/files/resources/policy-briefs/T-PB 17_Volker\%20Boege_Climate\%20Change \%20and\%20Conflict $\% 20$ in $\% 20$ Oceania.pd $f$, on March $26^{\text {th }}, 2020$.

Bourghelle, Valentine. "Climate change in the Security Council", accessed from https://voelkerrechtsblog.org/climate-change-in-the-security-council/ on June $24^{\text {th }}$, 2020

Bueger, Christian. "Security as Performation: Securitization, Piracy and the United Nations Security Council" In Zakopalova, Dagmar (2012), "Contextualizing the Process of Securitization: Construction of Security in the United Nations",MA Thesis Swiss Federal Institute of Technology Zurich, (2012); p. 12-14

Buzan, Barry, Waever, Ole and Wilde, Jaap de. "Security: A New Framework of Analysis", London :Lynne Riener Publisher, (1998); p. 23

Brown, Oli et al."Climate Change as the 'New' Security Threat: Implications for Africa", International Affairs (Royal Institute of International Affairs 1944), Vol. $83(6$, (2007); p. 1141-1154

Chotimah, Hidayat Chusnul. “ Analisis Strategi Keamanan Energi Cina dalam Upaya Penurunan Emisi Karbon melalui Pendekatan Konstruktivisme”, Jurnal Global, Vol. 19 No. 1 (2017) ; p. 29-43

COT Institute for Safety, Security and Crisis Management (2007). "Notions of Security Shifting

Concepts and Perspectives", (2007); p. 3-61 accessed from www.transnationalterorism.eu on June $21^{\text {st }}, 2020$

Cousins, Stephanie (2013). "UN Security Council: playing a role in the international climate change regime?", Global Change, Peace and Security, Vol. 25 (2), (2013); p. 191210

Corry, Olaf. "Securitisation and 'Riskification': Second-order Security and the Politics of Climate Change”, Millennium: Journal of International Studies, Vol. 40 (2), (2012); p. 235-258

Dupont, Claire. "The EU's collective securitisation of climate change", West European Politics,Vol. 42 (2), (2019); p. 369-390

Floyd, Rita. "Global climate security governance: a case of institutional and ideational fragmentation”, Conflict, Security \& Development, Vol.15 (2), (2015); p. 119-146 
Murni Kemala Dewi | Failure of Securitizing the Climate Change Issue at the United Nations Security Council (2007-2019)

Floyd, Rita."The Environmental Security Debate and its Significance for Climate Change", The International Spectator, Vol. 43 (3),(2008); p. 51-65

Hartmann, Betsy. "Rethinking Climate Refugees and Climate Conflict : Rhetoric, Reality and the Politics of Policy Discourse", Journal of International Development, Dev. 22, (2010); p.233-246

Huysmans, Jef. "Revisiting Copenhagen: Or About the Creative Development of a Security Studies Agenda in Europe", In Luiza-Maria Filimon, "An Overview of the Copenhagen School's Approach to Security Studies : Constructing (In) Security Through Performative Power", Asociatia Romana pentru Studii Baltice si Nordice, (2016); p. 53

Jackson, Nicole J. "International Organizations, Security Dichotomies and the Trafficking of Persons and Narcotics in Post-Soviet Central Asia: A Critique of the Securitization Framework", Security Dialogue, 37 (3),(2006); p.299-317

Kaldor, Mary (2012). "New and Old Wars 3rd Edition”, Polity Press, (2012); p.2

Keck, M., \& Sikkink, K. “Transnational Advocacy Networks in International Politics: Introduction”, In “Activists beyond Borders: Advocacy Networks in International Politics". Cornell University Press, retrieved from www.jstor.org/stable/10.7591/j.ctt5hh13f.4 March 25, 2020,

Kingdon, John W. “Agendas, alternatives and public policy”, Boston: Little Brown In Zakopalova, Dagmar. "Contextualizing the Process of Securitization: Construction of Security in the United Nations", MA Thesis Swiss Federal Institute of Technology Zurich, (2012); p.48

Kurniawan, Yandri. "The Politics of Securitization in Democratic Indonesia”, Palgrave Macmillan, (2018); p.19

Lassa, Jonatan. "Global Governance of Disaster Risk Reduction : An Introduction to a New Analytical Framework", Jurnal Global, Vol.10 No.1,(2010); p. 17

Little, Laura and Cocklin, Chris. "Environment and Human Security' in 'SAGE Handbooks of Environmental and Society", SAGE Publishing, (2007), p.451

Lucke, Franziskus von, et al. "What's at Stake in Securitising Climate Change? Towards a Differentiated Approach”, Geopolitics, Vol. 19,(2014); p. 857-884

Myers, N (1986). "The environmental dimension to security issues", The Environmentalist 6 (4),(1986); p. 251-257

$\mathrm{Ng}$, Trina. "Safeguarding Peace and Security in our Warming World: A Role for the Security Council”, Journal of Conflict \& Security Law, Vol. 15 (2), (2010); p. 275300

Nirbito, Annisa. "Radikalisme dalam Aksi Pergerakan Lingkungan: Studi Kasus terhadap Earth Liberation Front (Periode 1996-2011)”, Jurnal Global, Vol.15 No.2, (2013); p. 164

Peters, Katie. "Disasters, climate change, and securitisation: the United Nations Security Council and the United Kingdom's security policy", Disaster, Vol.42(2), (2018); p. $196-214$

Salter, Mark B. "Securitization and de-securitization: a dramaturgical analysis of the Canadian Air Transport Security Authority", Journal of International Relations and Development, 11 (4), (2008); p.321-349.

Salter, Mark B. "When Securitization Fails: The Hard Case of Counter-Terrorism Programs' In Balzacq, Thierry (ed.), "Securitization Theory: How Security Problems Emerge and Dissolve", London and New York, (2011); p.116-131.

Seiyefa, Ebimboere. "How climate change impacts on regional security in West Africa: Exploring the link to organised crime”, African Security Review, (2019); p. 2-13

Stritzel, Holger. "Towards a Theory of Securitization: Copenhagen and Beyond”, European 
Murni Kemala Dewi | Failure of Securitizing the Climate Change Issue at the

United Nations Security Council (2007-2019)

Journal of International Relations, Vol.13 No.3, (2007); p.357-383.

Tobing, Fredy Buhama Lumban. "Aktivitas Drug Trafficking sebagai Isu Keamanan yang Mengancam Stabilitas Negara", Jurnal Global, Vol.5 No.1, (2002); p. 75-76

United Nations. "Security Council Holds First-Ever Debate on Impact of Climate Change on Peace, Security, Hearing Over 50 Speakers", (2007a), accessd from https://www.un.org/press/en/2007/sc9000.doc.htm on June $21^{\text {st }}, 2020$

United Nations. "S/2007/186", (2007b) accessed from https://www.securitycouncilreport.org/atf/cf/\%7B65BFCF9B-6D27-4E9C-8CD3CF6E4FF96FF9\%7D/CC\%20S2007\%20186.pdf on June 21 ${ }^{\text {st }}, 2020$

United Nations. "Statement at the Security Council debate on energy, security and climate", (2007c), accessed from https://www.un.org/sg/en/content/sg/speeches/2007-0417/statement-security-council-debate-energy-security-and-climate, on June $25^{\text {th }}, 2020$

United Nations. "S/PV.5663: Energy, Security and Climate", (2007d)

United Nations. "A/64/350: Climate change and its possible security implications", Report of the Secretary-General, (2009)

United Nations. "S/PV.6587: Maintenance of international peace and security: Impact of climate change", (2011)

United Nations. "S/PV.8307: Maintenance of international peace and security: Understanding and addressing climate-related security risks, (2018)

United Nations. "S/PV.8451: Maintenance of international peace and security: Addressing the impacts of climate-related disasters on international peace and security", (2019)

United Nations. "UN Security Council Working Methods: The Veto”, (2020), accessed from https://www.securitycouncilreport.org/un-security-council-working-methods/theveto.php, on June $28^{\text {th }}, 2020$

Usigbe, Leon. "Drying Lake Chad Basin Gives Rise to Crisis", Africa Renewal, (2019), accessed from https://www.un.org/africarenewal/magazine/december-2019-march2020/drying-lake-chad-basin-gives-rise-crisis, on March $26^{\text {th }}, 2020$.

Waever, O. "Securitization and Desecuritization”. In: R.D. Lipschutz (ed.). “On Security”, New York: Columbia University Press, (1995); p. 46-87.

Warner, Jeroen dan Boas, Ingrid. "Securitization of climate change: How invoking global dangers for instrumental ends can backfire", EPC: Politics and Space, Vol. 37(8), (2019); p. 1471-1488

Werrell, Caitlin and Femia, Francesco (2019), "Sherri Goodman Talks "Threat Multiplier" on Yale Climate Connections", (2019), accessed from https://climateandsecurity.org/2019/06/27/sherri-goodman-talks-threat-multiplier-onyale-climate-connections/ on June $21^{\text {st }}, 2020$

Zakopalova, Dagmar. "Contextualizing the Process of Securitization: Construction of Security in the United Nations",MA Thesis, Swiss Federal Institute of Technology Zurich, (2012) 
Murni Kemala Dewi | Failure of Securitizing the Climate Change Issue at the United Nations Security Council (2007-2019)

\section{BIOGRAPHY}

The author is a graduate of the International Relations at Universitas Riau, currently pursuing a Master's degree in International Relations at University of Indonesia, and work as Public Relations of the Agency for Meteorology, Climatology and Geophysics of the Republic of Indonesia.

\section{Funding Acknowledgement:}

This work was supported by LPDP Scholarship of the Ministry of Finance of the Republic of Indonesia 